Kirja-arvio

\title{
Sven Dufvasta kaukopartioiden sankareihin
}

Jokinen, Arto. 2019. Isänmaan miehet. Maskuliinisuus, kansakunta ja väkivalta suomalaisessa sotakirjallisuudessa. Toim. Markku Soikkeli ja Ville Kivimäki. Tampere: Vastapaino. 296 sivua.

\section{Merja Leppälahti}

$\mathrm{I}$ sänmaan miehet on Arto Jokisen postuumisti julkaistu teos, jonka Markku Soikkeli on toimittanut julkaistavaan kuntoon Ville Kivimäen avustuksella. Kivimäki on kirjoittanut kirjaan esipuheen, jossa hän valottaa kirjan toimitustyötä ja siinä tehtyjä ratkaisuja. Isänmaan miehet on laadittu tietokirjaksi Jokisen väitöstutkimuksen materiaalin pohjalta. Jokisen työ jäi keskeneräiseksi: mukana oli sekä melko valmiita lukuja että osia, joissa oli vain viitteellisesti hahmoteltu tulevaa sisältöä. Esipuheessaan Kivimäki kertoo, etteivät kirjoittajat ryhtyneet arvailemaan eivätkä lisäilemään vaan lähinnä työstivät Jokisen omaa tekstiä eheämpään ja luettavampaan muotoon.

Arto Jokinen (1964-2016) kuului suomalaisen miestutkimuksen uranuurtajiin. Hänen lisensiaattitutkimuksensa poh-

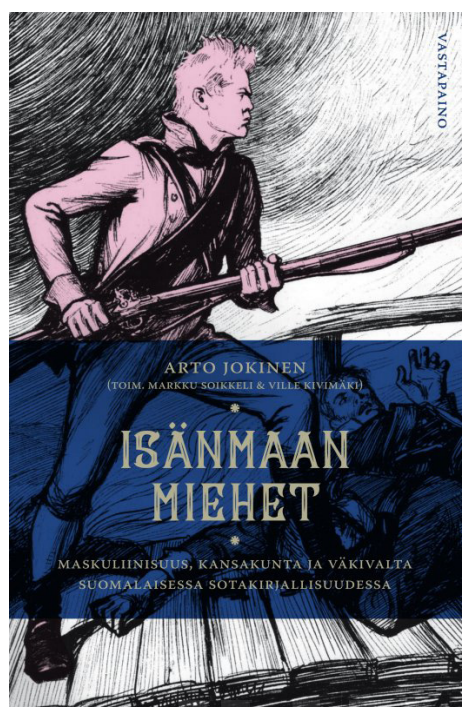
jalta julkaistulla teoksella Panssaroitu maskuliinisuus. Mies, väkivalta ja kulttuuri (2000) on ollut merkittävä rooli erityisesti sukupuolittuneen väkivallan tutkimuksessa. Teoksessa Jokinen tarkasteli erityisesti kulttuurisia tapoja ja merkkejä, joilla väkivalta liitettiin mieheyteen. Samaa aihetta hän jatkoi väitöstutkimuksessaan, jonka aineistona oli suomalainen sotakirjallisuus.

Vaikka aineistona on kirjallisuus, kysymyksessä ei ole ensisijaisesti kirjallisuudentutkimus vaan paremminkin sotakirjallisuuden sukupuolitietoista ja kulttuurintutkimuksellista luentaa. Teos lähtee liikkeelle Vänrikki Stoolin tarinoista, jonka jälkeen tarkastellaan vuoden 1918 tapahtumia käsitteleviä tekstejä. Niistä jatketaan talvi- ja jatkosodan kirjoihin. Luvussa "Päättymätön sota" tarkastellaan sotakirjallisuuden tilannetta 1950-luvulta nykyaikaan. 


\section{Teit' isäin astumaan}

Ensimmäisenä tarkastelun kohteena on Johan Ludvig Runebergin Vänrikki Stoolin tarinat. Teos julkaistiin ruotsiksi kahdessa osassa vuosina 1848 ja 1860 ja käännettiin suomeksi 1867-1889. Runot käsittelivät Ruotsin ja Venäjän sotaa vuosina 1808-1809. Ruotsi - jonka joukoissa suomalaiset taistelivat - hävisi sodan ja menetti Venäjälle itäisen maakuntansa Suomen. Runeberg käänsi hävityn sodan suomalaisten moraaliseksi voitoksi: kaikesta huolimatta suomalainen sotilas oli ihailtavan sankarillinen ja isänmaallinen.

Runoissa ihannoidaan sankarikuolemaa, vaikka se johtuisi suorastaan tyhmänrohkeasta toiminnasta taistelukentällä. Runeberg loi sankarirunoja, joissa näkyi isänmaanrakkaus, vaikka maata nimeltä Suomi ei ollut. Hänen esikuvinaan olivat antiikin sankarirunot. Jokinen on myös huomauttanut, että Paavo Cajanderin suomennoksessa alkuperäisten runojen 'sankarillisuuden' osoittaminen on usein käännöksessä muuttunut nimenomaan 'miehuuden' osoittamiseksi.

Kevät 1918 oli lyhyen mutta verisen sisällissodan aikaa. Tapahtumien jälkeen voittajapuolen näkemykset olivat hallitsevia kaikilla yhteiskunnallisilla ja kulttuurielämän aloilla. Voittajien sotakuvauksia alkoikin ilmestyä jo kesällä 1918. Jokinen on erotellut niistä kolme erilaista sodan kuvaamisen tapaa. Ensinnäkin korostettiin sotaa vapaussotana, jossa taisteltiin itsenäisyydestä. Toinen tulkinta korosti näkemystä veljessodasta ja kansallisesta tragediasta. Kolmas näkökulma tarkastelee tapahtumia yrittäen ymmärtää siihen johtanutta tilannetta. Näistä teksteistä Jokinen on analysoinut erityisestiV. A. Koskenniemen vuonna 1918julkaistua runoa "Nuori Anssi", jonka nuoren sotilaan hän yhdistää Runebergin "Sotilaspoika"-runoon.

Hävinneiden tekstejä julkaistiin aluksi ulkomailla. Suomessa niitä julkaistiin vasta sen jälkeen, kun kokijat palasivat vankileireiltä ja vankiloista. Osassa tekstejä kuvataan työlässankaruutta, jossa taistellaan aatteen ja parempien olosuhteiden puolesta. Painopiste on kuitenkin vankileirien ja vankeusaikojen, terrorin ja teloitusten kuvauksissa.

\section{Kansa taisteli, miehet kertovat}

Heti talvisodan jälkeen, vuosina 1940 ja 1941, julkaistiin 65 kaunokirjallista talvisotaa käsittelevää teosta sekä 60 tietokirjaa. Myöhemmin talvisotaa kuvattiin vähemmän, kunnes taas 1990 ja 2000-luvuilla talvisota on noussut jatkosotaa suositummaksi aiheeksi. Jokisen mukaan heti talvisodan jälkeen suosittiin pienoisromaaneja, joissa keskeistä oli halu kuvata aitoja tuntoja ja tapahtumia lähes dokumentaarisella tarkkuudella. Joissakin teoksissa on nähty runsaasti 1930-luvun militarismia, kansalliskiihkoa ja uskonnollisuutta, toisissa irrottauduttu yksilösankaruudesta ja pyritty kuvaamaan sotaa realistisesti kollektiivisena painajaisena. Talvisotaan liittyi myös ajatus suomalaisen sotilaan erityislaatuisesta kyvystä liikkua luonnossa: suomalainen metsästäjä-samoaja on synnynnäinen sotilas. Jokinen käsittelee myös niin sanottua talvisodan ihmettä ja talvisodan henkeä.

Jatkosodan alkuvaiheessa luettiin vielä talvisotakirjoja ja hyökkäysvaiheen taistelukuvauksia, mutta myöhemmin suosittiin viihdettä, esimerkiksi Armas J. Pullan Ryhmy ja Romppainen -romaaneja. Heti jatkosodan päätyttyä ei kirjoitettu niinkään sotakuvauksia vaan enemmänkin siviilielämään asettumisen ongelmista, ja varsinaiset sotakuvaukset yleistyivät hiukan myöhemmin. Sotien jälkeen monia talvi- ja jatkosodan kuvauksia poistettiin kirjastojen 
valikoimista poliittisesti arveluttavina - eli Neuvostoliitolle vihamielisinä - joko kokonaan tai ne siirrettiin suljettuihin varastoihin, "myrkkykaappiin". Useimpia näistä kirjoista oli silti mahdollista ostaa kirjakaupoista.

1950-luvulla sensuuri oli osin jo painunut unhoon, ja sotakirjojen suosio lähti nousuun. Silloin ilmestyivät muun muassa Väinö Linnan Tuntematon sotilas (1954) ja Veijo Meren Manillaköysi (1957). 1960- ja 1970-lukujen sotakirjoissa painotus oli dokumentaarinen, sen jälkeen viihteellinen. Jokinen asettaa esimerkiksi sisseistä ja kaukopartiomiehistä kertovan kirjallisuuden osittain eräkirjallisuuden jatkumoon: teoksissa etsitään usein miehen fyysisiä ja henkisiä rajoja rankoissa luonnonolosuhteissa, eli miehet taistelivat vihollisen lisäksi luonnonoloja vastaan. Erityisesti jatkosodan kirjojen yhteydessä Jokinen on käsitellyt myös kirjoissa kuvattua tappamisen problematiikkaa: toisaalta tappamisen vaikeutta, toisaalta tappamisen helppoutta ja hurmiota.

\section{Kun tarvitaan hyvää miestä}

Isänmaan miehet esittelee suuren joukon sotakirjoja kontekstualisoiden samalla niiden kirjoitustilanteita. Sotakirjallisuudessa kirjoittaja kertoo sodasta itse valitsemastaan näkökulmasta mutta yleensä ainakin jossain määrin tiettyjä, aikaan sidottuja konventioita noudattaen. Jokinen on tarkastellut sotakirjojen muuttuvia kuvauksia suomalaisesta sotilaasta. Runebergiläinen sotilas osasi kärsiä ja kuolla, mutta jatkosodassa miehet muuttuivat sotatyöläisiksi, joiden työnkuvaan kuului kylmäverinen tappaminen.

Suomessa asepalvelus ja siten myös mahdollinen sotaan osallistuminen ovat olleet pitkään sukupuolittuneita, ja siitä on tullut osa suomalaisten miesten tapaa olla miehiä. Sotakirjallisuus on kuvannut soturimaskuliinisuutta eri muodoissaan. Samalla sotakirjallisuus on kuvannut miehistä kansakunnan rakentamista sekä tulkinnut sotien syitä ja sotienjälkeistä aikaa. Miehisten sotasankarien ja muiden miestoimijoiden lisäksi Jokinen on tarkastellut lyhyesti myös sotakirjallisuuden kuvaamia naisrooleja. Niissäkin on vaihtelua, mutta soturius ei ole kuulunut naisen rooliin kuin poikkeuksellisesti: vuoden 1918 kertomuksissa naiset voivat olla sotureita naiseudestaan huolimatta, ei sen vuoksi. Ihannemaskuliinisuuteen näyttää sen sijaan Jokisen arvion mukaan kuuluvan valmius olla soturi: taistella ja kuollakin isänmaan puolesta.

Kirja olisi varmasti ollut jossain määrin toisenlainen, jos Jokinen olisi itse voinut saattaa sen valmiiksi, mutta toimittajat ovat tehneet hyvää työtä. Heidän käsissään Isänmaan miehistä on tullut ehjä ja ansiokas kokonaisuus melko vähän tutkitusta aiheesta.

\section{Kirjallisuus}

Jokinen, Arto. 2000. Panssaroitu maskuliinisuus. Mies, väkivalta ja kulttuuri. Tampere: Tampere University Press.

Filosofian lisensiaatti Merja Leppälahti on tietokirjailija ja kirjallisuuskriitikko sekä folkloristiikan tohtorikoulutettava Turun yliopistossa. 